\title{
PSYCHE.
}

\section{NOTES ON THE RELATIONS OF TWO CECIDOMYIANS TO FUNGI.}

\author{
BY WILLIAM TRELEASE, MADISON, WISC.
}

For some years, while collecting the commoner uredineae or rust fungi, my attention has been attracted by certain small orange-red insects, that are very frequent in and about some of the sori. They are most often noticed in the aecidia or cluster-cups and in those sori which contain uredo-spores. At times they are so abundant that it is almost impossible to collect a specimen of the commoner uredo or aecidial forms without finding numbers of them in nearly every sorus.

A first glance at them suggests that the insects may be some species of Thrips, but the resemblance vanishes on closer examination. Their motions, as a general thing, are less rapid than those of Thrips, and a hand-lens at once shows them to be some sort of dipterous larvae. With a higher power the breast-bone, characteristic of cecidomyid larvae, is distinctly seen. Various attempts have been made to bring them to maturity, but so far without success, so that it is as yet impossible to say anything definite about the species to which they belong.
The constant presence of these insects on the fruit of the fungi led me to watch their movements from time to time, and the reason for their presence was soon seen in the altered appearance of the sori where they were most numerous. Their relish for the spores is entirely disproportionate to the size of their minute bodies. The fact that they feed on the spores affords a simple explanation of their presence on the aecidial and uredo fruits, rather than in the teleutosporic sori of the rusts, since the spores of the latter are more frequently thick-walled and hard.

The fungi on which I have most often observed the larvae in question are Aecidium caladii, the cluster cup of Arisaema and other aroids, Coleosporium sonchi-arvensis, the common rust of $A$ ster and Solidago, and Caeoma nitens, the destructive red-rust everywhere abundant in spring on leaves of the blackberry and raspberry (Rubus).

$\mathrm{Mr}$. C. V. Riley informs me that he has also found the same larvae on a fungus (Exobasidium vaccinii?) growing on Azalea, and that they have been 
seen absolutely swarming on some fleshcolored fungus covering a squash, Cucurbita. The same, or very similar insects occur also in Europe, for M. Patouillard, speaking of Caeoma euonymi and Aecidium convallariae in the vicinity of Paris, says that their spores are frequently devoured by a small larva of an orange color. ${ }^{1}$

These larvae differ in their fungivorous habits from the greater number of cecidomyians, which feed on the juices of phaenogams, causing atrophy, as in the case of wheat attacked by Cecidomyia destructor, the hessian fly, or the development of galls such as most of the cecidomyidae produce. Some species, notably Cecidomyia tritici, the wheat fly, feed upon pollen, at least in the early part of their lives, in this respect approaching the species which eat spores. Aside from these, there are a few anomalous feeders in the genus. Westwood $^{2}$ states, on the authority of Vallot, whose work I have been unable to consult, that the larvae of one species are found on the under side of leaves of Chelidonium, sucking the acari found there; and Cecidomyia bicolor Meig. is said by Macquart to frequent the underside of the leaves of Leonurus, possibly for a similar purpose.

While the fungus-eating species are not sufficiently restricted in their choice of food to be classed as entirely injurious or entirely beneficial, they would

\footnotetext{
1 Bull. soc. bot. France, 28 May 1880 , v. 27 , p. 162 .

2 Introd. to mod. class. insects, v. 2, p. 5 19.
}

naturally fall among the useful species. Even the golden-rods and asters are of some importance to bee-keepers, and the onslaughts of the insects on the spores of the raspberry rust and other parasites of cultivated plants must tend to check the spread of these fungi, so that in a measure they protect the flowering plants on which they live, as does the species referred to by Vallot.

Entomologists are familiar with certain black spots, several millimetres in diameter, in the leaves of golden rods and asters. Solidago lanceolata and S. tenuifolia are more frequently marked in this manner than other species. These objects are found in the cabinets of economic entomologists as the galls of a gnat, Cecidomyia carbonifera $\mathrm{O}$. S. They also occur in the herbaria of mycologists as fungi, under the names Rhytisma solidaginis. and $R$. asteris given them a half century ago by Schweinitz.

On narrow-leaved species of Solidago, e.g., S. lanceolata, the spots, visible on both surfaces of the leaf, are sometimes almost circular, varying in diameter from I to $4 \mathrm{~mm}$.; but more commonly they are elongated parallel to the axis of the leaf, so as to be elliptical or oblong. They are usually symmetrical, unless the centre is situated at one side of the midrib of the narrow leaf, in which case the corresponding side is necessarily truncated on reaching the margin. The leaf is always slightly swollen in the discolored spot, but 
the enlargement occurs so uniformly in all parts that neither the midrib nor lateral nerves are obliterated. Now and then spots of the same nature are seen on the stem, where they are more irregular than on the leaf, and commonly occupy somewhat swollen portions of the internodes. The surface of the spot is of a dead coal-black, occasionally slightly glossy on the nerves. Sometimes the black passes into a deep purple at the edge of the spot, due to the presence of a soluble pigment in the diseased epidermal cells, this color changing gradually into the green of the surrounding leaf. In other cases it is bordered by a narrow white ring, forming a sharp line of demarcation between the black on the one hand and the green on the other, or more rarely separating the black from a purple zone, which gradually passes into the green.

On broader leaved species, like Solidago ulmifolia and $S$. caesia, the spots are more frequently round or slightly irregular, extending without interruption over the smaller veins or even the midrib. Though often glistening, they usually lack the coal-black appearance noticeable on S. lanceolata, and the reason for this is in some instances detected in a very delicate, whitish membrane, clearly continuous with the white or yellow border, which covers and modifies to a greater or less degree the black of the underlying parts. While some of the spots are no thicker than the unaffected portions of the leaf, others are strongly convex on one or both sides.

It has been said that Schweinitz called these fungi, and two species were made of them, characterized by their external features as follows : -

2034. Rhytisma solidaginis, L. v. S., vulgatissimum in foliis vigentibus Solidaginis lanceolatae nec alibi... R. innatum, aterrimum, absque ullo velo aut nitore, orbiculatum aut ovatum, margine luteo in folio; in pagina superiori convexum, in inferiori concavum; diametro I -6 linearum. Saepe plura confluunt-sed apertum non vidi.

2035. R. bifrons, L. v. S., rarum in folio Solidaginis sempervirentis... R. innatum, amphigenum, orbiculatum, gregarium aut subconfluens, convexum in ambabus paginis et satis crassum, margine in folio exalbescente. Sursum indutum cortice aut velo crassiore fusco-grisea exteriori, demum frustulis soluto, cortice interiori atra, intus carbonaceum. Diametro trilineari. Interdum perforatum invenitur, an casu?--ceterum inapertum.Schweinitz, Synopsis fung. Amer. bor. (Trans. Amer. philos. soc., 1831, n. s.,v. 4, p. 241.)

The spots on Aster leaves resemble those on the broad leaved species of Solidago in their general appearance, and vary even on the same plant from plane to strongly plano- or bi-convex. They are either entirely marginless or with a white or yellow border from 0.2-2 mm. in width. Occasionally the border is more or less tinged with red; this is especially the case where it is very broad. As with some specimens of the preceding species, the degree of convexity increases with age, the central portion of some spots being nearly hemispherical. Schweinitz at first referred this to the fungus genus Xyloma, but afterward transferred it to Rhytisma, and characterized it as follows :-

27r. Xyloma asteris S\%. X. minus oblongum ten. uius subeffiguratum rugosum nigrum opacum, ambitu suo folium decolorans. In foliis vigentibus Asteris tradescanti et aliorum rarissime. Initio et ipsum velo tenuissimo cinereo subtectum, rugosum, absque splendore.-Schrveinitz, Syn. fung. Carol. Super., (1822), p. 53 .

2033. Rhytisma asteris L. v. S., Syn. Car. 271, passim in foliis variorum Asterum .. Species quam distincta. R. innatum exacte orbiculatum, margine latiusculo exal. bescente, ambitu lobato, amphigenum, atrum sed expers nitoris, teniusculum, punctulatum: diametro bilineari, primum velo tenuissimo cinereo tectum demum evanes- 
cente. Dehiscens non mihi obvium. In planta ubi occurrit plerumque frequenter infestat folia. Schweinitz, Syn. fung. Amer. bor. (op. cit., p. 24r.)

It has been seen that the single or double convexity of these galls is not available as a distinctive character, although Schweinitz makes use of it. One of the most obvious superficial characters is the presence or absence of a white, gray or yellow membrane over the carbonized portion of the leaf. This, the velum of Schweinitz, is however by no means constantly absent or present in the same species, if we except that on Solidago lanceolata, where I have never seen it. On the same plant of $S$. ulmifolia some spots are black, while others are invested on both surfaces by the yellowish-white indusium; and one of the Osten Sacken types of the gall of Cecidomyia carbonifera, on a broad leaved Solidago, for an examination of which $\mathrm{I}$ am indebted to the courtesy of Dr. H. A. Hagen, is black above, with a narrow white border, while below it is completely covered by a white indusium, broken here and there as if by accident. With age this membrane frequently breaks away, but in the specimens to which the preceding statements refer the leaves were intact, and its absence was clearly not due to removal.

In their microscopic characters, all of these forms show a general agreement. The parenchyma of the leaf is invaded by a colorless mycelium of thick-walled hyphae, which lives between the cells and to a certain extent deforms them. It excites little if any hypertrophy, but by crowding the cells apart in its own growth causes the slight convexity of the part of the leaf in which it occurs. Near the surface the mycelial threads become brown, apparently as the result of some chemical action due to the fungus, which also affects the surrounding cells of the leaf, some of which are so completely carbonized that their walls are coal-black. In R. solidaginis and the other exindusiate forms, the epidermis is especially influenced by this change, which, however sometimes does not extend so far laterally as in the underlying tissue, - a fact which at once explains the pale border sometimes noticed; the dead but colorless epidermal cells at the margin of the spot, filled with air, appearing white, and contrasting strongly with the carbonized cells on the one hand and with the living ones on the other. 'The indusium of the other forms is of a similar nature to this border, consisting merely of the dead epidermis, filled with air; but why the epidermis should be blackened in some cases and remain colorless in others it is hard to say.

From what precedes it will be seen that only two of the three so-called species of Rhytisma are certainly distin. guishable in the specimens that I have examined, viz: $R$. solidaginis, on Solidago lanceolata and $S$. tenuifolia, and $R$. asteris (including $R$. bifrons) on Aster and the broader leaved species of Solidago. ${ }^{3}$ Curtis, whose herbarium, containing many Schweinitzian specimens, I have examined, through

\footnotetext{
3 The latter are referred by Berkeley to $R$. solidaginis (Grevillea, v. 4, p. 8).
} 
the kindness of Professor W. G. Farlow, was evidently of the same opinion, for his specimens bear only these two names, though some of the last named species occur on Solidago, and one, on Aster gracilis, agrees very well with the description of $R$. bifrons. Schweinitz, also, says of the three so-called species "Tres species antecedentes memorabiles inter se affines sunt." 4 The fruit of all is unknown. Like that of other species of Rhytisma, it does not develop on the living leaf, and I have been unable to look for it on the fallen leaves late in autumn or on the approach of the following spring. Possibly, when found, it may offer a means of distinguishing the so-called species more satisfactorily than can be done at present. Both species are widely distributed over the eastern third of the continent, from the Gulf states to New Brunswick.

The discussion of these objects from a botanical standpoint may appear to some readers unnecessary in an entomological journal, but no account of them would be complete without it. Turning, now, to the entomological side of their history, it remains to be said that several entomologists have bred from them one of the gall gnats - Cecidomyia carbonifera Osten Sacken. I, myself, have obtained the adult insects from what I have called $R$. asteris, and they are to be seen in some of the specimens in the Curtis herbarium, which have been broken. The Osten Sacken types, in the Museum of comparative zoology, would also undoubtedly be referred

${ }^{4}$ Syn. fung. Am. bor., l. r., p. $24 \mathrm{I}$. to this species by a mycologist. With the form on Solidago lanceolata I have been less successful, having never obtained the imago from it; but in the summer of I88I, while at Woods Holl, Mass., where this form was exceedingly common, I examined several hundred specimens on this plant, by breaking them open, and in every instance a living larva, evidently a cecidomyid, and apparently Cecidomyia carbonifera, was found in the substance of the gall, where it lay in a minute cavity. So far as I know, therefore, both insect and fungus are always present in these galls, to whichever species they are referred. While the slight convexity of the young gall is explained by the growth of the fungus, the hemispherical enlargement in many cases, especially on asters, seems to be caused by the insect, and these very thick spots, so far as I have examined them, always contain fully grown insects.

The first published intimation that these spots on Aster and Solidago are not simply insect galls or simply fungi, that I have noticed. is by Mr. W. R. Gerard, ${ }^{5}$ who, doubting their fungoid nature, sent specimens to $\mathrm{Mr}$. C. V. Riley, and was told that (at least so far as the forms on Solidago are concerned) they are the galls of $C$. carbonifera. Professor C. H. Peck also makes a similar statement in one of his later reports on New York fungi. ${ }^{6}$ Interested in the subject by these notes, I have examined

\footnotetext{
5 Bulletin Torrey bot. club, Oct. 1876, v. 6, p. 114 [Psyche, Rec., no. 2404].

6 29 Rept. N. Y. Cah. nat. hist., p. 81 .
} 
a large number of specimens from different parts of the country, and without exception have demonstrated their composite nature.

This compound character of the galls implies a close interdependence between the fungus and insect. That Rhytisma solidaginis or $R$. asteris cannot occur without the presence of Cecidomyia carbonifera, or vice versa, cannot be said; yet I have never seen one without the other. Only a study of the development of the galls can show whether the insect paves the way for the fungus or lives only in leaves previously attacked by the latter; but the great powers of multiplication and dissemination possessed by most fungi incline me to the belief that the former is the case, the mycelium being unable to penetrate the uninjured plant, as Hartig has shown to be the case with parasitic species of Nectria, etc. From the carbonization of all the species of Rhytisma, it is probable that the color of the galls in the present instance is due to the fungus.

The form of fruit of the Rhytisma, and the early development of the galls, could be easily made out by any collecting entomologist or botanist living in the eastern states, where they occur; and as I no longer have access to good material these notes are published in their present incomplete form to draw attention to a very interesting subject for further study. ${ }^{7}$

7 Sections of an undetermined cecidomyid gall on Impatiens fulva, from Medford, Mass., prepared in my labaratory by Miss L. N. Martin, show a mycelium somewhat similar to that noticed in Aster and Solidago leaves, and there is also a certain amount of carbonization. It will be interesting to observe whether the mycelium is always present in this gall which is not uncommon.

\section{WANT OF SYMMETRY AMONG INSECTS.}

BY OSKAR PAUI, KRANCHER, LEIPZIG, GERMANY.

The extraordinary symmetry which occurs among insects is usually brought prominently forward in most of the books which treat of entomology. Nothing is pictured more symmetrically than, for: instance, the structures of bees and ants, or the color of butterflies, which latter is prominently reputed to have a perfectly symmetrical bilateral equality. Although there is much truth at the bottom of all this, although nature in many cases works with great symmetry, yet it must not be orerlooked that even this symmetry is often converted into its strict opposite. Surely no observing lepidopterologist has failed to notice that the coloration of the wings of his favorites is to be recognized as strictly symmetrical only in the smallest number of cases, that, indeed, that of one side, which certainly resembles that of the other in its superficial aspect, still shows many differences in its details, and there is little foundation for asserting that they are symmetrical. I might cite innumerable examples of this, but the reader can better see them for himself. This is most plainly shown in the 

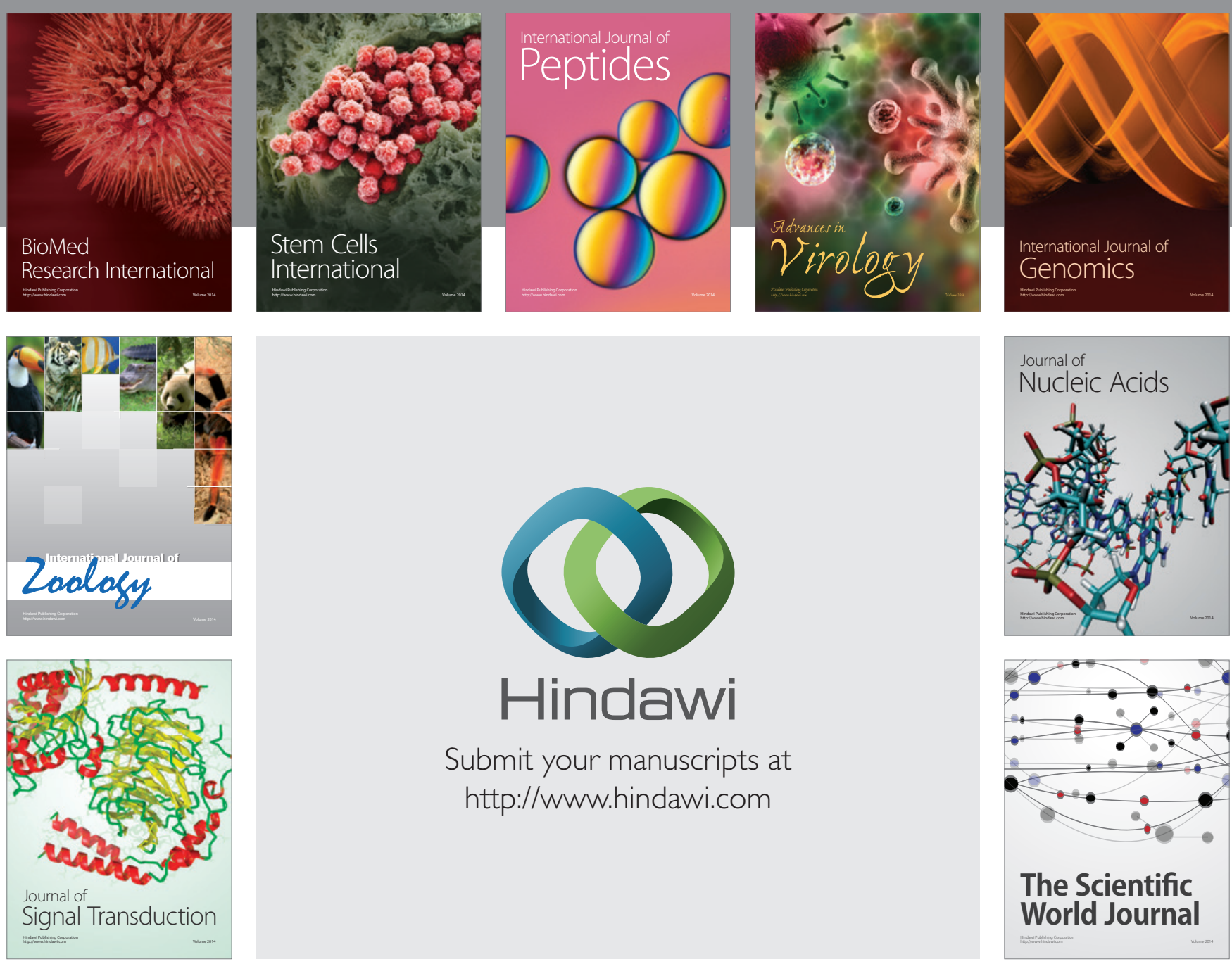

Submit your manuscripts at

http://www.hindawi.com
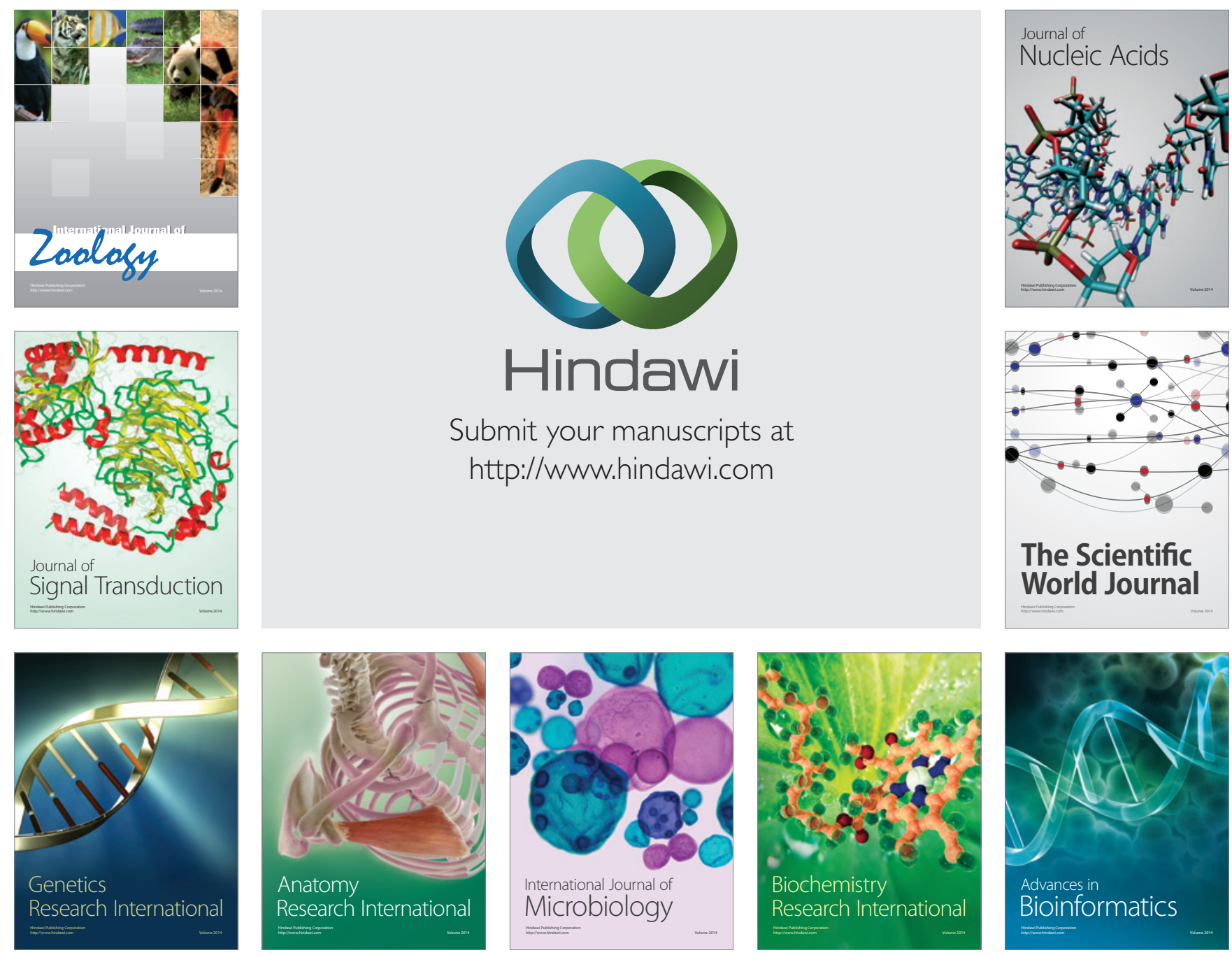

The Scientific World Journal
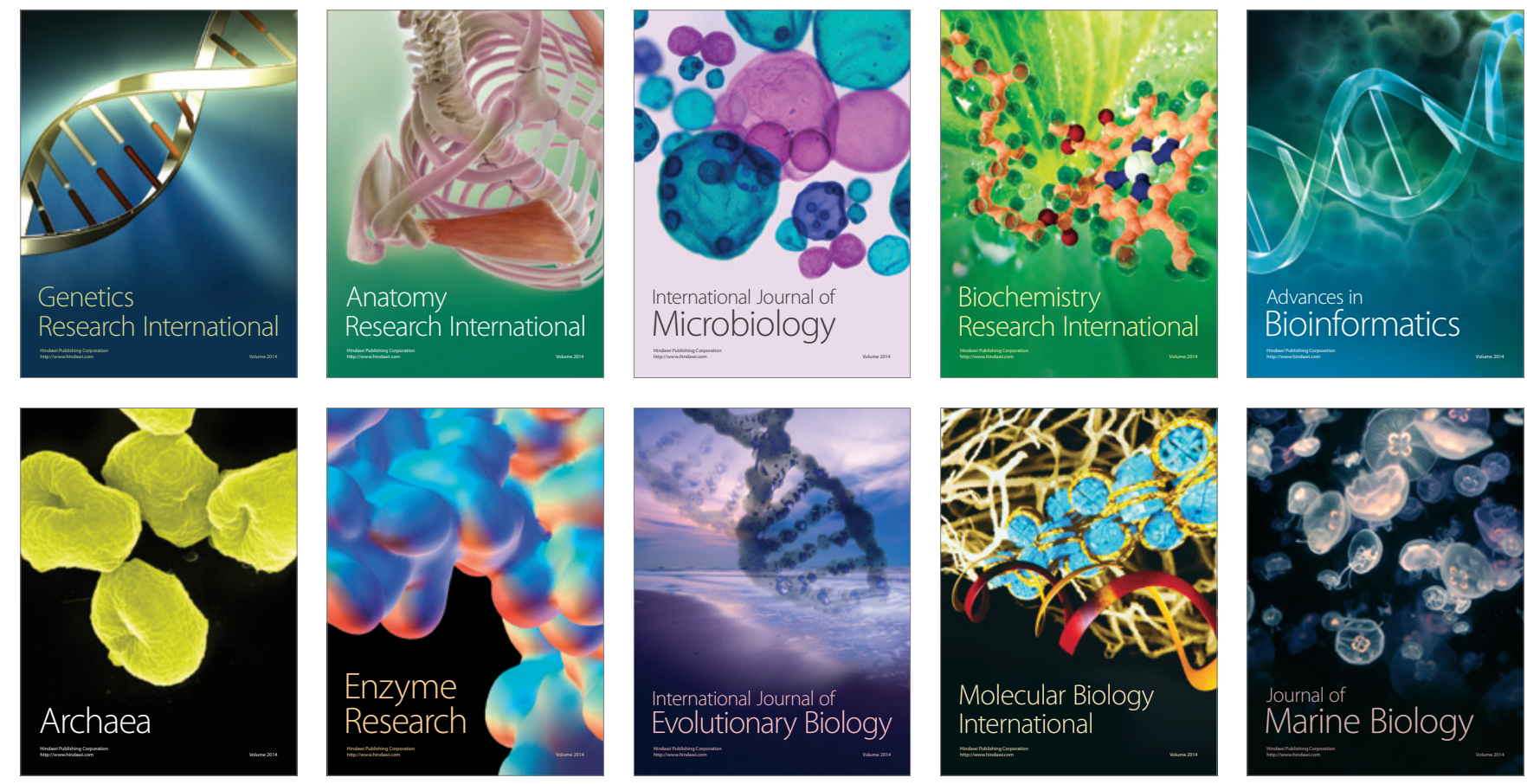